\title{
DISPATCHING OF ROBOTIC CONTROL PROGRAMS
}

\author{
E. V. Larkin ${ }^{1}$, elarkin@mail.ru, \\ V. V. Kotov ${ }^{1}$, vkotov@list.ru, \\ A. N. Ivutin ${ }^{1}$, alexey.ivutin@gmail.com, \\ A. N. Privalov ${ }^{2}$, privalov.61@mail.ru. \\ 1 Tula State University, Tula, Russian Federation \\ 2 Tula State Pedagogical University, Tula, Russian Federation
}

\begin{abstract}
The problem of dispatching discipline choice when managing programs are linked into unified multi-loop computer control system is considered. It is shown that a problem of control of such a system may be reduced to the problem of evaluation of states both robot and controller. In multi-circuit computer control systems time intervals of residence of robot in any state depends on both time complexity of control algorithm and dispatching discipline. Two simplest disciplines of most common use are investigated: the cyclic dispatching and foreground (quasi-stochastic) one. With use the formalism of semi-Markov process models of functioning of control programs under investigated dispatching disciplines are worked out. Mathematical relationships for time of return to any state of semi-Markov process and time between switches are obtained. The parameters obtained are essential for choice the efficient regimes of data processing when control of robots.
\end{abstract}

Keywords: robot, multi-circuit control, data processing, dispatching discipline, cyclic, quasi-stochastic, semi-Markov process, time of return, time between switches.

\section{Introduction}

Main feature of computer control system of robots is their multi-functionality. When multi-circuit object is under digital control emerges the task of evaluation of system states in every current time. As a rule, in real single-processor control systems operation of managing software modules resides under control of the dispatching program, which defines, what module must be executed the next $[1,2,3]$.

Organization of priorities of programs execution is defined by discipline of dispatching. Due to the features of robot (constrained number of modules, rigid limits for time complexity, etc.) discipline of dispatching must be extremely simple [4,5].

One of the features of operation of onboard computer, which control a functioning equipment of robots, is a steady data stream between them, sensors and servos. In the case it is expedient to apply the cyclic scheduling disciplines. In such routines no task has advantages over the other. Program launching is implemented on timer (synchronous disciplines) or on signals of feedback, after completion of previous program (asynchronous disciplines).

Priority scheduling disciplines also are applied for operation with steady data streams, but the programs are executed in routine, defined with predetermined priorities. First of all are processed data with highest priority, and then - with lower. Data processing lasts until the list of tusks in queue complete, or finish time of cycle. For steady functioning of digital control circuits both programs of processing of signal with wider spectrum (consequently with higher sampling frequency) and programs with lower computational complexity would have higher level of priority. Despite of rigid content of dispatching algorithms for external 
observer sequence of execution of programs in onboard computer is unpredictable. This fact permits to call this scheduling discipline the quasi-stochastic one.

Exactly because the simplicity of their realization and stability of operation, cyclic and quasi-stochastic scheduling disciplines are rather of widely used in a control systems of robots. When soft of robots is designed, functioning of dispatching programs is planned in advance: demands to sampling frequency and semantic of signals processing is defined, and schedule prepared with taking into account time characteristics of system and applied software. So for proper planning of computational process time coordination of functioning of control circuits is necessary, and evaluation of time factor of soft is quite actual task. When evaluation of time factor it is necessary to divide functioning of robot onto the states and to define both the residence of robot in its states and switching the states of robot.

It is possible to evaluate the system states when there is proper approach to simulation of software operation. The fundamental theory of semi-Markov process is widely used for such purpose. So, the fundamental theory of semi-Markov process may be used to obtain necessary expressions $[6,7,8]$.

\section{Generalized Models of Cyclic and Foreground Dispatching Disciplines}

Models of cyclic and foreground dispatching disciplines are different in principle.

In cyclic (simplest) discipline software modules are executed in turn, one after another. Order of priority is exactly pre-determined. Generalized structure of such order is shown on Fig. 1, where $A_{1}, \ldots, A_{m}, \ldots, A_{M}$ are the software modules of robot.

In foreground disciplines there is no strict sequence on starting of software modules. In embedded systems order of execution is determined by current condition of units under control [9]. Due to the fact proper software module may be starts up in any time. So, for external observer a selection of modules by dispatching program is occasional and such disciplines may be called quasi-stochastic (Fig. 2). In generalized structure of quasi-stochastic disciplines $A$ is the model of dispatching operator, which distributes management to proper module in accordance with algorithm embedded into controller.

The models of both disciplines are formed from semi-Markov processes

$$
\mu_{m}=\left\{A_{m}, \boldsymbol{h}_{m}(t)\right\} ; \quad 0 \leq m \leq M
$$

where $A_{m}$ is a set of states of $m$-th process; $\boldsymbol{h}_{m}(t)=\left\lfloor h_{j(m), n(m)}(t)\right\rfloor$ is a semi-Markov matrix; $t$ is a time; $1 \leq j(m), n(m) \leq J(m)$.

Without loss of generality it is possible to assume that in set $A_{m}=a_{1(m)}, \ldots, a_{j(m)}, \ldots, a_{J(m)}$ state $a_{1(m)}$ is the initial one, and state $a_{J(m)}$ is the absorbing one (Fig. 1) [10]. Due to the fact that semi-Markov processes $\mu_{m}$ are the models of real software modules of embedded systems, each state of subset $a_{2(m)}, \ldots, a_{j(m)}, \ldots, a_{J(m)}$ is attainable from $a_{1(m)}$, and state $a_{J(m)}$ is attainable from $a_{1(m)}, \ldots, a_{j(m)}, \ldots, a_{J(m)-1}$. Thus in semi-Markov matrices $\boldsymbol{h}_{m}(t) h_{j(m), n(m)}(t)=0$ for $0 \leq j(m) \leq J(M)$.

With use of formulas, which were obtained in [11], time of reaching $a_{J(m)}$ from $a_{1(m)}$ 


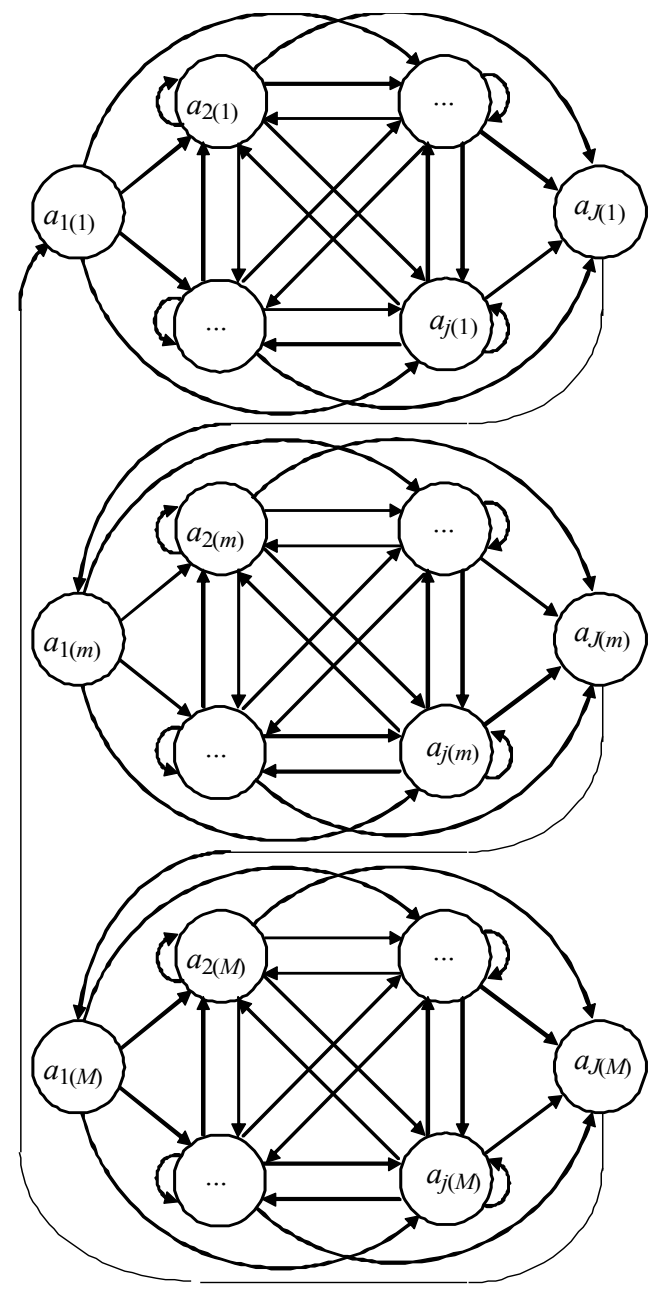

Fig. 1. Structure of cyclic dispatching disciplines

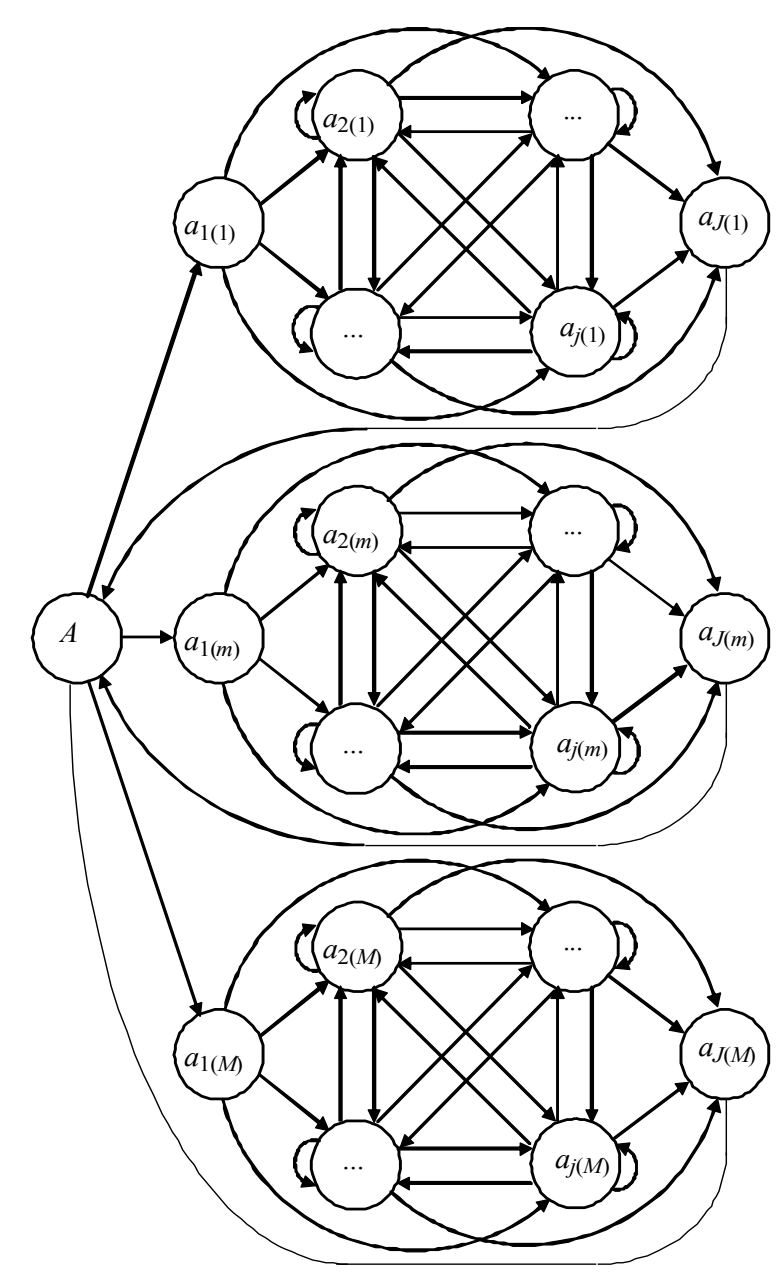

Fig. 2. Structure of quasi-stochastic dispatching discipline

may be defined:

$$
f_{m}(t)=L^{-1}\left\lceil{ }^{1} \boldsymbol{I}_{1(m)} \cdot \sum_{k=1}^{\infty}\left\{L\left[\boldsymbol{h}_{m}(t)\right]\right\}^{k} \cdot{ }^{C} \boldsymbol{I}_{J(m)}\right\rceil
$$

where ${ }^{1} \boldsymbol{I}_{1(m)}$ is a row vector in which first element is equal to one, and all other elements are equal to zeros; ${ }^{C} \boldsymbol{I}_{J(m)}$ is a column vector in which $J(m)$-th element is equal to one, and all other elements are equal to zeros; $L\lceil\ldots\rceil$ and $L^{-1}\lceil\ldots\rceil$ are direct and inverse Laplace transforms, correspondingly.

Expectation and dispersion of time of reaching $a_{J(m)}$ from $a_{1(m)}$ are the next

$$
\begin{gathered}
T_{m}=\int_{0}^{\infty} t \cdot L^{-1}\left[{ }^{1} \boldsymbol{I}_{1(m)} \cdot \sum_{k=1}^{\infty}\left\{L\left[\boldsymbol{h}_{m}(t)\right]\right\}^{k} \cdot{ }^{C} \boldsymbol{I}_{J(m)}\right\rceil d t \\
D_{m}=\int_{0}^{\infty}\left(t-T_{m}\right) \cdot L^{-1}\left\lceil{ }^{1} \boldsymbol{I}_{1(m)} \cdot \sum_{k=1}^{\infty}\left\{L\left[\boldsymbol{h}_{m}(t)\right]\right\}^{k} \cdot{ }^{C} \boldsymbol{I}_{J(m)}\right\rceil d t .
\end{gathered}
$$




\section{Parameters of Cyclic Dispatching Disciplines}

Semi-Markov matrix describing the cyclic dispatching discipline is as follows:

$$
c_{\boldsymbol{h}(t)}=\left\lfloor c_{h_{m, n}(t)}\right\rfloor,
$$

where

$$
c_{h_{m, n}(t)}= \begin{cases}f_{m}(t) & \text { when } 1 \leq m \leq M-1, n=m+1 ; \text { or when } m=M, n=1 ; \\ 0 & \text { in all other cases. }\end{cases}
$$

It is simple to prove, that semi-Markov process (3) is the recurrent and ergodic one. For ergodic semi-Markov process (3):

- density of time of return to $m$-th state is defined as

$$
{ }^{c} g_{m}(t)=L^{-1}\left[\prod_{m=1}^{M} L\left[f_{m}(t)\right]\right]
$$

and it is quite equal to all software modules;

- minimal, average and maximal time of returning are equal to

$$
{ }^{c} \tau_{\text {min }}=\sum_{m=1}^{M} T_{m \text { min }} ;{ }^{c} \tau_{\text {mid }}=\sum_{m=1}^{M} T_{m} ;{ }^{c} \tau_{\max }=\sum_{m=1}^{M} T_{m \max }
$$

where $T_{m \text { min }}, T_{m}, T_{m \text { max }}$ are the lower limit of range of definition, expectation and the upper limit of range of definition $f_{m}(t)$, correspondingly.

Dispersion of time of returning to any state is equal to ${ }^{c} D=\sum_{m=1}^{M} D_{m}$.

These parameters are equal for all states of semi-Markov process (3). Besides, for said process:

- the probability of residence in $m$-th state for an external observer is equal to $[12,13]$

$$
{ }^{c} \pi_{m i d}=\frac{T_{m}}{{ }^{c} \tau_{m i d}}
$$

- the expectation of time between switches is equal to

$$
{ }^{c} g_{m}(t)=\sum_{m=1}^{M} \pi_{m} f_{m}(t)
$$

Average time and dispersion of time between switches are equal to

$$
\begin{gathered}
{ }^{c} T=\int_{0}^{\infty} t \sum_{m=1}^{M} \pi_{m} f_{m}(t) d t \\
{ }^{c} \widetilde{D}=\int_{0}^{\infty}\left(t-{ }^{c} T\right)^{2} \sum_{m=1}^{M} \pi_{m} f_{m}(t) d t .
\end{gathered}
$$




\section{Parameters of Quasi-Stochastic Dispatching Discipline}

Semi-Markov matrix describing the quasi-stochastic dispatching discipline has dimension $(M+1) \times(M+1)$ and is as follows

$$
{ }^{Q} \boldsymbol{h}(t)=\left[{ }^{Q} h_{m, n}(t)\right]
$$

where

$$
{ }^{Q} h_{m, n}(t)=\left\{\begin{aligned}
{ }^{d} p_{n} \cdot{ }^{d} f_{n}(t), & \text { when } m=0 \text { and } 1 \leq m \leq M ; \\
f_{n}(t), & \text { when } 1 \leq m \leq M, n=0 ; \\
0, & \text { in all other cases. }
\end{aligned}\right.
$$

${ }^{d} p_{n}$ is a probability of choice by dispatcher the $n$-th software module after completion execution of a current program; ${ }^{d} f_{n}(t)$ is a density of time of operation of dispatcher when choosing $n$-th software module.

It is simple to prove, that semi-Markov process (5) is the recurrent and ergodic one. In ergodic semi-Markov process there are differences in expressions for time intervals of returning the process into state $A_{0}$, and into states $A_{1}, \ldots, A_{m}, \ldots, A_{M}$.

The density of time of returning to state $A_{0}$ is as follows:

$$
Q_{g_{0}(t)}=\left[\sum_{m=1}^{M}{ }^{d} p_{m} \cdot L\left[{ }^{d} f_{m}(t)\right] \cdot L\left[f_{m}(t)\right]\right] .
$$

Minimal, average and maximal time of returning to state $A_{0}$ is equal to:

$$
\begin{gathered}
{ }^{Q} \tau_{\min 0}=\min \left(T_{m \min }+{ }^{d} T_{m \min }\right) \\
{ }_{\tau_{\operatorname{mid} 0}}=\sum_{m=1}^{M}{ }^{d} p_{n}\left(T_{m}+{ }^{d} T_{m}\right) ; \\
{ }^{Q} \tau_{\max 0}=\min \left(T_{m \max }+{ }^{d} T_{m \max }\right),
\end{gathered}
$$

where ${ }^{d} T_{m \text { min }},{ }^{d} T_{m},{ }^{d} T_{m \max }$ are the lower limit of range of definition, expectation and the upper limit of range of definition ${ }^{d} f_{m}(t)$, correspondingly.

Dispersion of time of returning to state $A_{0}$ is equal to

$$
{ }^{Q} D_{g_{0}}=\sum_{m=1}^{M}{ }^{d} p_{m}\left[\left(T_{m}+{ }^{d} T_{m \text { min }}\right)^{2}+D_{m}+{ }^{d} D_{m \text { min }}\right]-{ }^{Q} \tau_{\text {mid } 0}^{2}
$$

Density of time of returning to $m$-th state is as follows

$$
{ }^{Q} g_{m}(t)=L^{-1}\left[\boldsymbol{I}_{r} \cdot \sum_{k=1}^{\infty}\left[L\left(\widetilde{\boldsymbol{h}}_{m}\right)(t)\right]^{k} \cdot \boldsymbol{I}_{c}\right]
$$

where

$$
\begin{gathered}
\widetilde{\boldsymbol{h}}_{m}=\left[\begin{array}{cc}
\widetilde{h}_{0,0}(t) & \widetilde{h}_{m, m}(t) \\
0 & 0
\end{array}\right] ; \\
\widetilde{h}_{0,0}(t)=L^{-1}\left[\sum_{\substack{n=1, n \neq m}}^{M} L\left[{ }^{d} p_{n} \cdot{ }^{d} f_{n}(t)\right] \cdot L\left[{ }^{d} f_{n}(t)\right]\right] ;
\end{gathered}
$$




$$
\begin{gathered}
\widetilde{h}_{m, m}(t)=L^{-1}\left[L\left[{ }^{d} p_{m} \cdot{ }^{d} f_{m}(t)\right] \cdot L\left[f_{m}(t)\right]\right] ; \\
\boldsymbol{I}_{c}=\left(\begin{array}{c}
0 \\
1
\end{array}\right) ; \quad \boldsymbol{I}_{r}=(0,1) ; \quad 1 \leq m \leq M .
\end{gathered}
$$

Minimal, average and maximal time of returning to $m$-th state is equal to:

$$
\begin{gathered}
{ }^{Q} \tau_{\min m}=\min \left(T_{m \min }+{ }^{d} T_{m \min }\right) \\
{ }^{Q} \tau_{\text {mid } m}={ }^{d} T_{m}+T_{m}+\frac{1}{{ }^{d} p_{m}} \cdot\left(1-{ }^{d} p_{m}\right) \cdot \sum_{\substack{n=1, n \neq m}}^{M}{ }^{d} p_{m}\left({ }^{d} T_{n}+T_{n}\right) ; \\
{ }^{Q} \tau_{\max m}=\infty .
\end{gathered}
$$

The dispersion of time of returning to $m$-th state is as follows:

$$
{ }^{Q} D_{m}={ }^{d} D_{m}+D_{m}+\frac{\widetilde{D}_{m, m} \cdot\left(1-{ }^{d} p_{m}\right)}{{ }^{d} p_{m}}+\frac{T_{m, m}^{2} \cdot\left(1-{ }^{d} p_{m}\right)}{{ }^{d} p_{m}^{2}},
$$

where

$$
\widetilde{D}_{m, m}=\frac{1}{1-{ }^{d} p_{m}} \cdot \sum_{\substack{n=1, n \neq m}}^{M}{ }^{d} p_{n} \cdot\left[{ }^{d} D_{n}+D_{n}+\left({ }^{d} T_{n}+T_{n}\right)^{2}\right]-\left[\frac{1}{1-d p_{m}} \cdot \sum_{\substack{n=1, n \neq m}}^{M}{ }^{d} p_{n}\left({ }^{d} T_{n}+T_{n}\right)\right]^{2} .
$$

Besides, for said process:

- probability of residence in $m$-th state for an external observer

$$
\begin{aligned}
& { }^{Q} \pi_{0}=\frac{\sum_{m=1}^{M}{ }^{d} p_{m} \cdot{ }^{d} T_{m}}{{ }^{Q} \tau_{\text {mid } 0}} ; \\
& { }^{Q} \pi_{m}=\frac{T_{m}}{{ }_{\tau_{\text {mid } m}}} ; 1 \leq m \leq M,
\end{aligned}
$$

- density of time between switches

$$
{ }^{Q} g(t)={ }^{Q} \pi_{0} \sum_{m=1}^{M}{ }^{d} p_{m} \cdot{ }^{d} f_{m}(t)+\sum_{m=1}^{M}{ }^{Q} \pi_{m} f_{m}(t) .
$$

For time between switching average time and dispersion can be found as

$$
\begin{gathered}
{ }^{Q} T=\int_{0}^{\infty} t \cdot\left[{ }^{Q} \pi_{0} \sum_{m=1}^{M}{ }^{d} p_{m} \cdot{ }^{d} f_{m}(t)+\sum_{m=1}^{M}{ }^{Q} \pi_{m} f_{m}(t)\right] d t \\
{ }^{Q} D=\int_{0}^{\infty}\left(t-{ }^{Q} T\right) \cdot\left[{ }^{Q} \pi_{0} \sum_{m=1}^{M}{ }^{d} p_{m} \cdot{ }^{d} f_{m}(t)+\sum_{m=1}^{M}{ }^{Q} \pi_{m} f_{m}(t)\right] d t
\end{gathered}
$$




\section{Experiment}

Experimental verification of proposed method was carried out on models, structures of which are shown in Fig. 3.

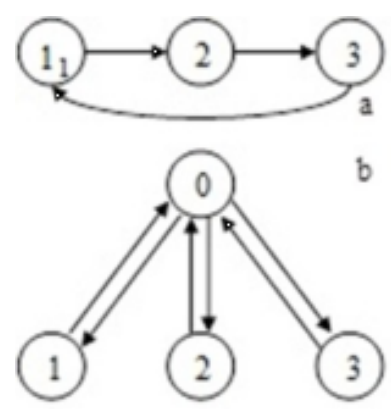

Fig. 3. Examples of cyclic (a) and quasi-stochastic (b) disciplines of dispatching

Densities of time of programs execution in every cases are described by the uniform distribution law

$$
f_{m}(t)= \begin{cases}2, & \text { when } 0,75 \leq t \leq 1,25 \\ 0, & \text { in all other cases }\end{cases}
$$

Density of time of execution of dispatching program is described by the uniform distribution law

$$
f_{0}(t)= \begin{cases}2, & \text { when } 3,75 \leq t \leq 0,625 \\ 0, & \text { in all other cases }\end{cases}
$$

Theoretical results received were verified experimentally using the Monte-Carlo method [14]. Histograms of time of return cyclic process into state $1^{C} g_{1}(t)$, and time between switching ${ }^{C} g(t)$ are shown in Fig. 4. Experimental evaluation of expectation of time ${ }^{C} T_{1}=3,012$ gives an error $0,4 \%$. Experimental evaluation of expectation of time ${ }^{C} T=1,005$ gives an error $0,5 \%$.

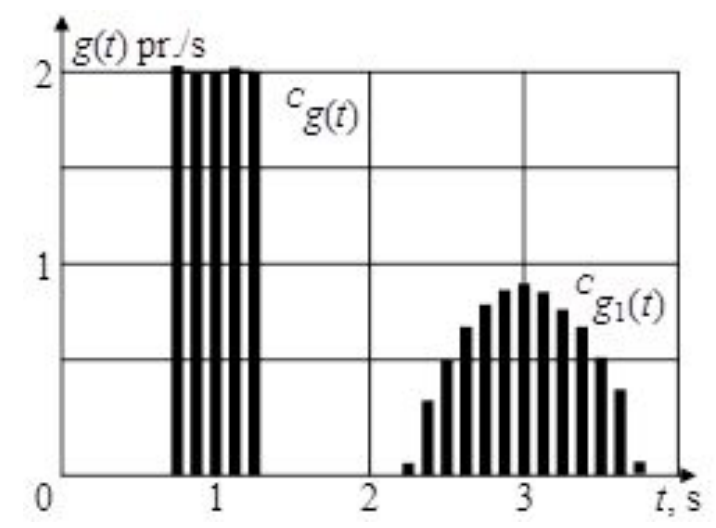

Fig. 4. Histograms of time of return into state $1{ }^{C} g_{1}(t)$, and time between switching ${ }^{C} g(t)$ in the case of cyclic discipline of dispatching

Histograms of time between of return cyclic process into state $0{ }^{Q} g_{0}(t)$, and time between switching ${ }^{Q} g(t)$ are shown in Fig. 5. Experimental evaluation of expectation of time ${ }^{Q} T_{0}=1,509$ gives an error 0,6\%. Experimental evaluation of expectation of time ${ }^{Q_{T}}=0,830$ gives an error $0,48 \%$. 


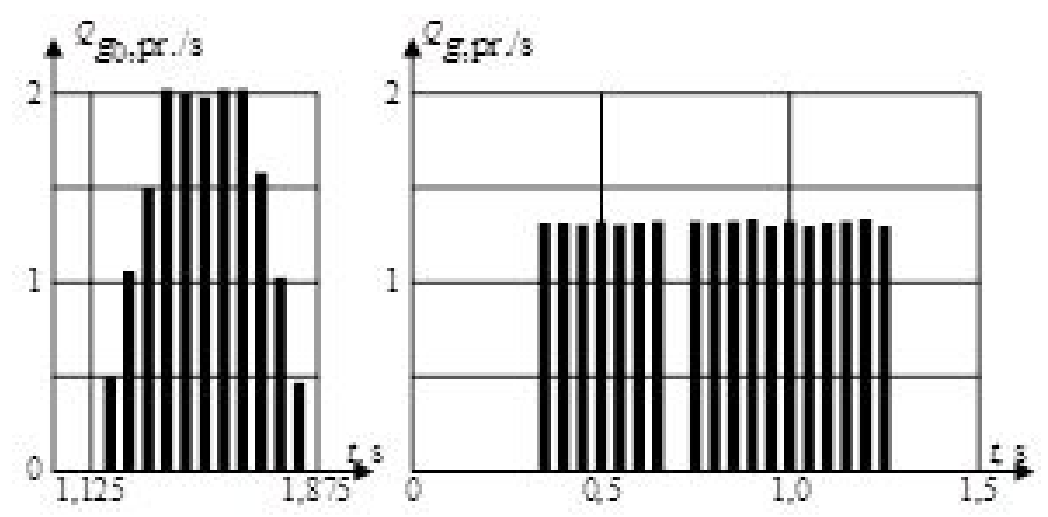

Fig. 5. Histograms of time of return into state $0{ }^{Q} g_{0}(t)$, and time between switching ${ }^{Q} g(t)$ in the case of quasi-stochastic

\section{Conclusion}

So in the article main relations between time complexities of software modules, dispatching discipline, time and probabilistic characteristics of dispatcher in complex, multi-circuit computer control systems of robots are obtained. For cyclic discipline, the variation of time complexities of software modules is the only possibility of control the time intervals between transactions. When quasi-stochastic discipline, to the time complexities the algorithm of selection of modules is supplemented. The algorithm, in turn, defines probabilities (frequencies) of launching the software modules.

Time intervals are significantly important parameter from point of view insertion the computer into control circuit as the feedback element. Optimization of time under consideration permits to improve quality characteristics of control. Results obtained permit to ensure the required limits of time intervals, for example, to achieve time intervals when polling regime fulfill the requirements of Nyquist-Shannon sampling theorem. Further research in this area may be directed onto working out the method of optimization of time intervals in multi-circuit computer control systems of robots.

The reported study was partially supported by RFBR and Tula Region Government, research project no. 16-41-710160 r_a.

\section{References}

1. Tzafestas S.G. Introduction to mobile robot control. Elsevier, 2013.

2. Kahar S., Sulaiman R., Prabuwono A., Ahmad N. A Review of Wireless Technology Usage for Mobile Robot Controller. 2012 International Conference on System Engineering and Modeling (ICSEM 2012) IPCSIT. 2012, pp. 7-12. http://www.ipcsit.com/vol34/002-ICSEM2012-M0004.pdf

3. Wang Z., Liang M., Maropoulos P.G. High accuracy mobile robot positioning using external large volume metrology instruments. International Journal of Computer Integrated Manufacturing.Taylor \& Francis. 2011, vol. 24, no. 5, pp. 484-492. doi: 10.1080/0951192X.2011.554868 
4. Olsson G. Piani G. Computer Systems for Automation and Control, Nevskij dialekt, 2001.

5. Hyytiä E., Penttinen A., Aalto S. Size-and state-aware dispatching problem with queue-specific job sizes. European Journal of Operational Research, 2012, vol. 217, no. 2, pp. 357-370. doi: 10.1016/j.ejor.2011.09.029

6. Vishnevsky V., Dudin A., Klimenok V., Semenova O., Shpilev S. Approximate Method to Study M/G/1-Type Polling System with Adaptive Polling Mechanism. Quality Technology \&s Quantitative Management, 2012, vol. 9, no. 2, pp. 211-228.

7. Howard A. Dynamic Probabilistic Systems, Volume I: Markov Models, Courier Corporation, 2012.

8. Howard A. Dynamic Probabilistic Systems, Volume II: Semi-Markov and Decision Processes, Courier Corporation, 2013.

9. Meerschaert M., Straka P. [et al.] Semi-Markov approach to continuous time random walk limit processes. The Annals of Probability, 2014, vol. 42, no. 4, pp. 1699-1723. doi: 10.1214/13-AOP905.

10. Iverson M., Özgüner F., Follen G. Run-time statistical estimation of task execution times for heterogeneous distributed computing. High Performance Distributed Computing, 1996., Proceedings of 5th IEEE International Symposium on. IEEE, 1996, pp. 263-270.

11. Ivutin A., Larkin E. Estimation of latency in embedded real-time systems. 2014 3rd Mediterranean Conference on Embedded Computing (MECO). Institute of Electrical \& Electronics Engineers (IEEE), 2014, pp. 236-239. doi: 10.1109/meco.2014.6862704

12. Ivutin A., Larkin E., Lutskov Y. Evaluation of program controlled objects states Embedded Computing (MECO), 2015 4th Mediterranean Conference on. IEEE, 2015, pp. 250-253.

13. Ivutin A., Larkin E., Kotov V. Established Routine of Swarm Monitoring Systems Functioning. Advances in Swarm and Computational Intelligence Springer Science + Business Media, 2015, pp. 415-422. doi: 10.1007/978-3-319-20472-7_45

14. Fishman G. Monte Carlo: concepts, algorithms, and applications. Springer Science \& Business Media, 2013.

Eugene V. Larkin, Doctor of Technical Science, Professor, Department of Robotics and Industry Mechanization, Tula State University (Tula, Russian Federation), elarkin@mail.ru.

Vladislav V. Kotov, Doctor of Technical Science, Associate Professor, Department of Robotics and Industry Mechanization, Tula State University (Tula, Russian Federation), vkotov@list.ru

Alexey N. Ivutin, Candidate of Technical Sciences, Associate Professor, Department of Computer Technology, Tula State University (Tula, Russian Federation), alexey.ivutin@gmail.com 
Alexander N. Privalov, Doctor of Technical Science, Professor, Department of Informatics and Information Technology, Tula State Pedagogical University (Tula, Russian Federation), privalov.61@mail.ru

Received June 7, 2016

УДК 004.942

DOI: $10.14529 /$ jcem1602002

\title{
ДИСПЕТЧЕРИЗАЦИЯ В ПРОГРАММАХ УПРАВЛЕНИЯ МОБИЛЬНЫМИ РОБОТАМИ
}

\author{
Е. В. Ларкин, В. В. Котов, А. Н. Ивутин, А. Н. Привалов
}

\begin{abstract}
Рассматривается проблема выбора дисциплины диспетчеризации для случая, когда управляющие программы объединены в одной многоконтурной системе управления. Показано, что задача управления такой системой может быть сведена к проблеме оценки состояний робота и контроллера. В многоконтурной системе управления временные интервалы нахождения робота в любом из состояний зависят от временной сложности алгоритма управления и дисциплины диспетчеризации. Исследованы две наиболее простых и наиболее распространенных схемы диспетчеризации: циклическая и квазистохастическая. Для исследуемых дисциплин диспетчеризации с применением полумарковских процессов разработаны модели функционирования управляющих программ. Получены математические соотношения для определения времени возврата к любому состоянию полумарковского процесса и времени между переключениями. Полученные параметры необходимы для выбора эффективных режимов обработки данных при роботизированном управлении.

Ключевые слова: робот, многоконтурная система управления, обработка данных, дисциплина диспетчеризации, ииклическал, квазистохастическал, полумарковский процесс, время возврата, время между переключениями.
\end{abstract}

\section{Литература}

1. Tzafestas, S.G. Introduction to mobile robot control / S.G. Tzafestas. - Elsevier, 2013.

2. Kahar, S. A Review of Wireless Technology Usage for Mobile Robot Controller S. Kahar, R. Sulaiman, A. Prabuwono, N. Ahmad // 2012 International Conference on System Engineering and Modeling (ICSEM 2012) IPCSIT. - 2012. - P. 7-12. http://www.ipcsit.com/vol34/002-ICSEM2012-M0004.pdf

3. Wang, Z. High accuracy mobile robot positioning using external large volume metrology instruments / Z. Wang, M. Liang, P.G. Maropoulos // International Journal of Computer Integrated Manufacturing. - 2011. - V. 24, №. 5. - P. 484-492.

4. Олссон, Г. Цифровые системы автоматизации и управления / Г. Олссон, Д. Пиани. - Невский диалект, 2001.

5. Hyytiä, E. Size-and state-aware dispatching problem with queue-specific job sizes E. Hyytiä, A. Penttinen, S. Aalto // European Journal of Operational Research. 2012. - V. 217, № 2. - P. 357-370. 
6. Vishnevsky, V. Approximate Method to Study M/G/1-Type Polling System with Adaptive Polling Mechanism / V. Vishnevsky, A. Dudin, V. Klimenok, O. Semenova, S. Shpilev // Quality Technology \& Quantitative Management. - 2012. - V. 9, № 2. P. 211-228.

7. Howard, A. Dynamic Probabilistic Systems. Volume I: Markov Models / A. Howard. Courier Corporation, 2012.

8. Howard, A. Dynamic Probabilistic Systems. Volume II: Semi-Markov and Decision Processes / A. Howard. - Courier Corporation, 2013.

9. Meerschaert, M. Semi-Markov approach to continuous time random walk limit processes / M. Meerschaert, P. Straka. // The Annals of Probability. - 2014. - V. 42, № 4. - P. 1699-1723.

10. Iverson, M. Run-time statistical estimation of task execution times for heterogeneous distributed computing / M. Iverson, F. Özgüner, G. Follen // High Performance Distributed Computing, 1996., Proceedings of 5th IEEE International Symposium on. IEEE. - 1996. - P. 263-270.

11. Ivutin, A. Estimation of latency in embedded real-time systems / A. Ivutin, E. Larkin // 2014 3rd Mediterranean Conference on Embedded Computing (MECO). Institute of Electrical \& Electronics Engineers (IEEE). - 2014. - P. 236-239.

12. Ivutin, A. Evaluation of program controlled objects states / A. Ivutin, E. Larkin, Y. Lutskov // Embedded Computing (MECO), 2015 4th Mediterranean Conference on IEEE. - 2015. - P. 250-253.

13. Ivutin, A. Established Routine of Swarm Monitoring Systems Functioning / A. Ivutin, E. Larkin, V. Kotov // Advances in Swarm and Computational Intelligence Springer Science + Business Media. - 2015. - P. 415-422.

14. Fishman, G. Monte Carlo: concepts, algorithms, and applications / G. Fishman. Springer Science \& Business Media, 2013

Ларкин Евгений Васильевич, доктор технических наук, профессор, кафедра «Робототехника и автоматизация производства», Тульский государственный универcumem (2. Тула, Российская Федерачия), elarkin@mail.ru.

Котов Владислав Викторович, доктор технических наук, дочент, кафедра «Робототехника и автоматизачия производства», Тульский государственный универcumem (ә. Тула, Российская Федерачия), vkotov@list.ru.

Ивутин Алексей Николаевич, кандидат технических наук, доцент, кафедра «Вычислительная техника», Тульский государственный университет (г. Тула, Российская Федерачия), alexey.ivutin@gmail.com.

Привалов Александр Николаевич, доктор технических наук, профессор, кафедра «Информатика и информачионные технологии», Тульский государственный педагогический университет (г. Тула, Российская Федерачия), privalov.61@таil.ru.

Поступила в редакцию 7 июня 2016 г. 